\title{
PENYULUHAN PENDIDIKAN KARAKTER KEPADA GURU SMP KOTA BEKASI
}

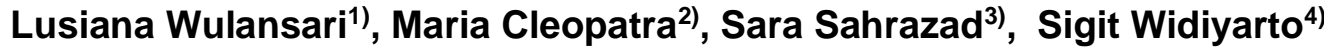 \\ 1,3)Program Studi Pendidikan Bimbingan dan Konseling, \\ 2)Program Studi Teknik Informatika, ${ }^{4)}$ Program Studi Pendidikan Ekonomi \\ 1,2,3,4)Universitas Indraprasta PGRI Jakarta \\ 1)Iusianawulansari58@gmail.com, 2)mariacleopatra1313@gmail.com, \\ ${ }^{4)}$ Sara.sahrazad@gmail.com, ${ }^{4}$ sigit.widiyanto372@gmail.com
}

\section{Histori artikel}

Received:

2 November 2020

Accepted:

29 November 2020

Published:

30 November 2020

\begin{abstract}
Abstrak
Kegiatan pengabdian kepada masyarakat dilatarbelakangi pentingnya pendidikan karakter para siswa, agar mereka dapat mencapai tujuan hidupnya kelak. Penyuluhan ini dirasakan penting, sebab masih banyak karakter menyimpang yang dilakukan oleh anak dibawah umur. Baik itu nilai - nilai kesusilaan dan moral. Tujuan penyuluhan ini, untuk meningkatkan dan memperkuat pola pendidikan karakter pada guru SMP dengan cara pembiasaan dan menjadi tauladan bagi para siswa. Data dikumpulkan dalam catatan harian/jurnal harian. Sedangkan contoh tauladan dapat dicatat dalam RPP dan buku laporan harian guru. Pelaksanaan kegiatan ini menggunakan metode penyuluhan tatap muka berbasis protokol kesehatan, pemberian materi, praktik dan pendampingan, serta evaluasi dan wawancara tiap semester Kegiatan ini diikuti oleh 16 guru bidang studi dan staf tata usaha sebanyak 4 orang pada SMP Yadika 4 Kota Bekasi. Kegiatan dilakukan dengan new normal dimana diterapkan protokol kesehatan yang ketat, agar pelaksanaan berjalan dengan baik dan aman. Kegiatan pengabdian kepada masyarakat ini berlangsung dari bulan Agustus sampai dengan September 2020. Hasil kegiatan menunjukkan pada hasil soal studi kasus yang telah diberikan oleh tim kepada para guru, nampak rata-rata hasil dari evaluasi sebesar 78 (kategori baik), dari hasil wawancara menunjukkan para guru kurang konsisten dalam menanamkan karakter, namun setelah diadakan kegiatan ini, mereka lebih percaya diri dan termotivasi. Para orang tua juga harus membantu pembentukan karakter para siswa, agar siswa merasa diperhatikan dan selalu membiasakan karakter dirumah maupun disekolah.
\end{abstract}

Kata-kata kunci: penyuluhan guru, pendidikan karakter 
Abstract. Community service activities are motivated by the importance of character education for students, so that they can achieve their life goals in the future. This counseling is felt to be important, because there are still many deviant characters carried out by minors. Whether it's ethical and moral values. The purpose of this counseling is to improve and strengthen the character education pattern of junior high school teachers by habituating and becoming role models for students. Data is collected in a daily diary / daily journal. While exemplary examples can be recorded in the lesson plan and the teacher's daily report book. The implementation of this activity uses face-to-face counseling methods based on health protocols, providing materials, practice and mentoring, as well as evaluation and interviews each semester. This activity was attended by 16 teachers of the field of study and 4 administrative staff at SMP Yadika 4 Bekasi City. Activities are carried out with the new normal where strict health protocols are applied, so that implementation runs well and safely. This community service activity takes place from August to September 2020. The results of the activity show the results of the case study questions that the team has given to the teachers, it appears that the average results of the evaluation are 78 (good category), the results of the interviews show that the teachers are less consistent in instilling character, but after this activity, they are more confident and motivated. Parents must also help shape the character of students, so that students feel cared for and always get used to character at home and at school.

Keywords: counseling for teacher, character education

\section{PENDAHULUAN}

Indonesia adalah negara yang menjunjung tinggi nilai - nilai kebenaran dan karakter yang berbudi luhur. Untuk itulah Indonesia memerlukan insan manusia yang berkarakter, berkompetitif serta menguasai ilmu pengetahuan dan teknologi termasuk bahasa asing (Widiyarto, Wulansari, dan Hasanusi, 2020). Nilai tersebut tidak mengabaikan aspek dasar nilai keagamaan supaya dapat menghasilkan produk dengan kualitas-kualitas yang lebih baik. Untuk memenuhi sumber daya manusia tersebut, pendidikan memiliki peran yang sangat penting. Hal ini sesuai dengan UU No 20 Tahun 2003 Tentang Sistem Pendidikan Nasional pada Pasal 3, yang menyebutkan bahwa "Pendidikan nasional berfungsi mengembangkan kemampuan dan membentuk karakter serta peradaban bangsa yang bermartabat dalam rangka mencerdaskan kehidupan bangsa". Pendidikan merupakan salah satu proses dalam membentuk, mengarahkan dan mengembangkan kepribadian serta kemampuan seseorang. Pendidikan yang baik dan berkualtias juga turut menentukan pembelajaran karakter itu sendiri (Widiyarto dan Sartono, 2020).

Untuk bisa mencapai pribadi yang bermoral, salah satu cara yang dapat dilakukan adalah memberikan pembelajaran secara efektif, efisien, dan menarik atau dalam bahasa sekarang disebut dengan PAIKEM (Praktis, Aktif, Inovatif, Kreatif, dan Menyenangkan) untuk dapat mencapai pembelajaran karakter yang berkualitas, perlu dirancang strategi yang inovatif (Maunah, 2015). Pada 2500 tahun yang lalu Socrates dalam buku Anasufi Banawi, mengatakan tujuan yang melandasi pendidikan adalah untuk membuat seseorang menjadi baik dan cerdas. Manusia yang terdidik seharusnya menjadi orang bijak, yaitu orang yang dapat menggunakan ilmunya untuk hal-hal yang baik (beramal sholeh) dan dapat hidup secara bijak dalam seluruh aspek kehidupan keluarga, bertetangga, bermasyarakat dan bernegara. Oleh karenanya sebuah sistem pendidikan yang berhasil adalah yang dapat membentuk manusia-manusia berkarakter yang sangat diperlukan dalam mewujudkan 
sebuah negara kebangsaan terhormat. Pendidikan karakter merupakan bentuk kegiatan manusia yang di dalamnya terdapat suatu tindakan yang mendidik diperuntukkan bagi generasi selanjutnya. Tujuan pendidikan karakter adalah untuk membentuk penyempurnaan diri individu secara terus-menerus dan melatih kemampuan diri demi menuju ke arah hidup yang lebih baik (Ati, Cleopatra, dan Widiyarto, 2020).

Selanjutnya karakter itu sendiri merupakan nilai-nilai perilaku manusia yang berhubungan dengan Tuhan Yang Maha Esa, diri sendiri, sesama manusia, lingkungan, dan kebangsaan yang terwujud dalam pikiran, sikap, perasaan, perkataan, dan perbuatan berdasarkan norma-norma agama, hukum, tata krama, budaya, dan adat istiadat (Widiyarto dan Sartono, 2020). Pendidikan karakter dapat diterapkan dalam pembelajaran pada setiap mata pelajaran. Materi pembelajaran yang berkaitan dengan norma atau nilai-nilai pada setiap mata pelajaran perlu dikembangkan, dieksplisitkan, dikaitkan dengan konteks kehidupan sehari-hari. Dengan demikian, pembelajaran nilai-nilai karakter tidak hanya pada tataran kognitif, tetapi menyentuh pada internalisasi, dan pengalaman nyata dalam kehidupan peserta didik sehari-hari di masyarakat. Pendidikan karakter di sekolah sangat terkait dengan manajemen atau pengelolaan sekolah (Supandi dkk., 2020). Pengelolaan yang dimaksud adalah bagaimana pendidikan karakter direncanakan, dilaksanakan, dan dikendalikan dalam kegiatan-kegiatan pendidikan di sekolah secara memadai. Pengelolaan tersebut antara lain meliputi, nilai-nilai yang perlu ditanamkan, muatan kurikulum, pembelajaran, penilaian, pendidik dan tenaga kependidikan, dan komponen terkait lainnya. Namun, ada hal-hal yang tidak bisa digantikan oleh teknologi, yaitu keikhlasan, rendah hati, dan nilai-nilai karakter baikdari seorang guru (Ati, Cleopatra, dan Widiyarto, 2020). Dengan demikian, manajemen sekolah merupakan salah satu media yang efektif dalam pendidikan karakter di sekolah.

Dewasa ini masyarakat menuntut peningkatan intensitas dan kualitas pelaksanaan pendidikan karakter pada lembaga pendidikan formal. Tuntutan tersebut didasarkan pada fenomena sosial yang berkembang, yakni meningkatnya kenakalan remaja dalam masyarakat (Sukiyani, 2004), seperti perkelahian massal dan berbagai kasus dekadensi moral lainnya. Bahkan di kota-kota besar tertentu, gejala tersebut telah sampai pada taraf yang sangat meresahkan. Oleh karena itu, lembaga pendidikan formal sebagai wadah resmi pembinaan generasi muda diharapkan dapat meningkatkan peranannya dalam pembentukan kepribadian peserta didik dan membentuk karakter sejak dini melalui peningkatan intensitas dan kualitas pendidikan karakter (Sunarmintyastuti dkk., 2020)

Masalah lain yang tengah dihadapi oleh bangsa Indonesia adalah sistem pendidikan dini yang ada sekarang ini terlalu berorientasi pada pengembangan otak kiri (kognitif) dan kurang memperhatikan pengembangan otak kanan (afektif dan empati). Padahal, pengembangan karakter lebih berkaitan dengan optimalisasi fungsi otak kanan. Mata 
pelajaran yang berkaitan dengan pendidikan karakter pun (seperti budi pekerti dan agama) ternyata pada praktiknya lebih menekankan pada aspek otak kiri (hafalan). Pembentukan karakter harus dilakukan secara sistematis dan berkesinambungan yang melibatkan aspek knowledge, feeling, loving, dan acting. Pada dasarnya, anak yang kualitas karakternya rendah adalah anak yang tingkat perkembangan emosi-sosialnya rendah, sehingga anak beresiko besar mengalami kesulitan dalam belajar, berinteraksi sosial, dan tidak mampu mengontrol diri. Berbagai masalah bangsa Indonesia di berbagai bidang selama ini tidak lepas dari karakter dan nilai-nilai masyarakat. Kalau saat ini banyak kritik yang terkait dengan karakter bangsa, maka sekolah sebagai salah satu lembaga pendidikan, ikut bertanggung jawab untuk mengatasi permasalahan tersebut. Sebagian orang berpandangan bahwa kondisi demikian diduga bermula dari apa yang dihasilkan oleh dunia pendidikan. Pendidikanlah yang sesungguhnya paling besar memberikan kontribusi terhadap rendahnya karakter (Sudrajat, 2010). Anak-anak yang telah melewati sistem pendidikan selama ini, mulai dari pendidikan sekolah kurang memiliki kemampuan mengelola konflik dan kekacauan, sehingga anak-anak dan remaja selalu menjadi korban konflik dari kekacauan tersebut.

\section{METODE PELAKSANAAN}

Pelaksanaan kegiatan ini menggunakan metode penyuluhan tatap muka berbasis protokol kesehatan, pemberian materi, praktik dan pendampingan, serta evaluasi dan wawancara tiap semester. Kegiatan berlangsung pada bulan Agustus sampai dengan September 2020, di SMP Yadika 4 Jakarta Barat. Adapun jadwal dan materi penyuluhan sebagai berikut:

Tabel. 1. Materi Penyuluhan

\begin{tabular}{clcc}
\hline No & \multicolumn{1}{c}{ Materi } & Durasi & Jadwal \\
\hline 1 & $\begin{array}{l}\text { Integrasi } \\
\text { Pendidikan } \\
\text { Karakter }\end{array}$ & 60 Menit & 10 Agustus 2020 \\
\hline 2 & $\begin{array}{l}\text { Muatan Pendidikan } \\
\text { karakter }\end{array}$ & 90 Menit & 25 Agustus 2020 \\
\hline 3 & Aplikasi karakter & 60 menit & $\begin{array}{c}10 \text { September } \\
2020\end{array}$ \\
\hline 4 & tanya jawab & 60 menit & $\begin{array}{c}12 \text { September } \\
2020\end{array}$ \\
\hline
\end{tabular}

Kegiatan penyuluhan dilaksanakan dengan melibatkan masyarakat dan berkoordisasi dengan keseluruhan setempat, karena kegiatan harus melalui izin. Hal ini dilakukan agar, pihak sekolah selalu terjaga dari virus corona. Tim menggunakan masker dan alat alat pelindung diri seperti, hand sanitizer dan lain - lain. 


\section{HASIL DAN PEMBAHASAN}

Pada kegiatan pengabdian kepada masyarakat, setelah mendapat izin dari pengurus $\mathrm{RT} / \mathrm{RW}$ setempat, tim melakukan berbagai persiapan, seperti menyiapkan alat infokus, hand out dan beberapa video yag akan ditayangkan oleh tim kepada para guru dan staff TU.

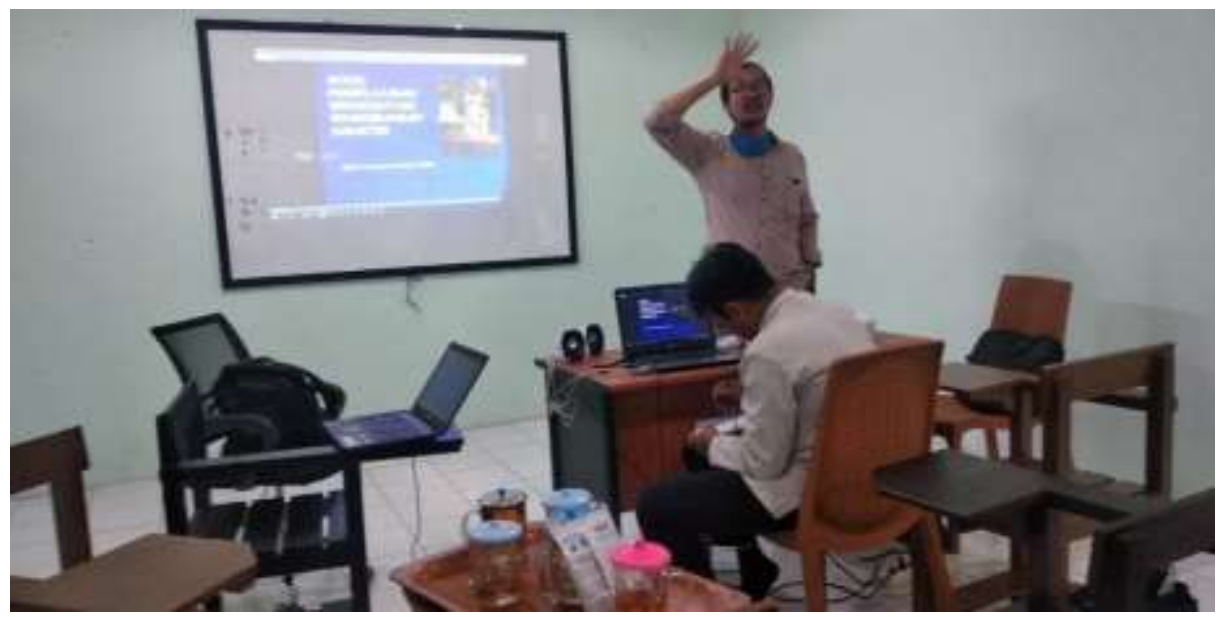

Gambar 1. Tim sedang memaparkan materi pembelajaran karakter

Pelaksanaan penyuluhan materi sesi 1, 2 dan 3 berjalan dengan lancar. Para guru diberikan kesempatan untuk bertanya, adapun pertanyaan yang dapat dirangkum oleh tim adalah sebagai berikut:

Metode apa yang baik dalam penerapan karakter pada siswa nanti, kedua, bagaimana memantau perkembangan karakter siswa, agar para orang tua dan guru selalu dapat mengawasi pertanyaan ketiga, berikan contoh nyata, bagaimana menangani siswa yang berkarakter kurang terpuji. Pada akhir penyuluhan ini, tim akan mengolah data para guru, berisikan kegiatan penanaman karakter dan sejauh mana para guru dapat menjadi suri tauladan kepada para siswa. Kegiatan tersebut dilakukan dengan tatap muka penyuluan, praktik berbudi luhur dalam lingkungan sekolah dan rumah. Tim memberikan evaluasi berupa soal studi kasus. Para guru menerangkan tahapan langkah penanaman karakter kepada siswa melalui jawaban yang mereka isi. Setelah mengisi soal studi kasus tersebut, tim mengadakan wawancara kepada para guru.

Tim juga memberi kesempatan kepada para guru untuk bertanya. Beberapa pertanyaan lain, masih ada, namun secara umum, ke 3 pertanyaan tersebut paling dominan ditanya oleh para guru dan staff TU. Tim menjawab pola pengajaran karakter dan memberikan contoh nyata pembelajaran karakter dengan baik. Di antaranya tim menjelaskan bahwa implementasi pendidikan nilai. Berkenaan dengan keteladanan. Pengimplementasian pendidikan nilai kepada peserta didik memerlukan adanya kesadaran para pendidik agar senantiasa menjadi contoh bagi peserta didik agar tidak bersikap mendua (Vernia dkk., 2020). Misalnya, jika peserta didik dituntut berperilaku jujur, berucap dengan upacan yang baik, konsekuensinya para pendidik dituntut berperilaku jujur, tidak mengajarkan 
kebohongan, dan bertutur kata yang baik. Sebagai konsekuensinya, para pendidik (orang tua, guru, dan para pembimbing) harus konsisten dalam berperilaku moral karena peserta didik tumbuh dan berkembang mengikuti model perilaku para pendidik. Mereka akan melakukan apa yang dilakukan dan dikatakan oleh si pendidik. Para pendidik hendaknya selalu memelihara nilai diajarkan dan konsisten dalam berperilaku. Keluarga pada hakikatnya merupakan wadah pembentukan karakter masing-masing anggotanya, terutama anak-anak yang masih berada dalam bimbingan dan tanggung jawab orang tuanya (Sukiyani, 2014). Pada hasil soal studi kasus yang telah diberikan oleh tim kepada para guru, nampak rata-rata hasil dari evaluasi sebesar 78 (kategori baik), dari hasil wawancara menunjukkan para guru kurang konsisten dalam menanamkan karakter, namun setelah diadakan kegiatan ini, mereka lebih percaya diri dan termotivasi.

\section{KESIMPULAN}

Pembelajaran karakter sangat strategis dilaksanakan. Pada hasil soal studi kasus yang telah diberikan oleh tim kepada para guru, nampak rata-rata hasil dari evaluasi sebesar 78 (kategori baik), dari hasil wawancara menunjukkan para guru kurang konsisten dalam menanamkan karakter, namun setelah diadakan kegiatan ini, mereka lebih percaya diri dan termotivasi. Sebelum diadakan kegiatan ini, karakter siswa yang optimal, dengan upaya dan strategi para guru, penanaman karakter sudah dapat diaplikasikan bertahap. Kegiatan ini harus dibarengi oleh karakter para guru yang baik. Para orang tua juga harus membantu pembentukan karakter para siswa, agar siswa merasa diperhatikan dan selalu membiasakan karakter dirumah maupun disekolah.

\section{DAFTAR PUSTAKA}

Akhmad, S. (2010). Konsep pengambilan keputusan dalam manajemen pendidikan. [Online]. Diterima melalui http://Akhmadsudrajat.wordpress.com. Diakses Tanggal 10 Oktober 2015

Ati, A. P., Cleopatra, M., \& Widiyarto, S. (2020). Strategi pembelajaran dan pengajaran menulis bahasa Indonesia: Tantangan di era revolusi industri 4.0. Prosiding Samasta.

Hadi, S., Puspita, F., Ati, A. P., \& Widiyarto, S. (2020). Penyuluhan dan pembelajaran karakter melalui pelaksanaan idul adha pada siswa SMA. Jurnal Pemberdayaan: Publikasi Hasil Pengabdian Kepada Masyarakat, 4(2), 205-210.

Maunah, B. (2015). Implementasi pendidikan karakter dalam pembentukan kepribadian holistik siswa. Jurnal Pendidikan Karakter, (1).

Sukiyani, F. (2014). Pendidikan karakter dalam lingkungan keluarga. SOCIA: Jurnal IImuIImu Sosial, 11(1). 
Sunarmintyastuti, L., \& Suprapto, H. A. (2020). Pengembangan SDM melalui minat dan motivasi santriwati pada Yayasan Taufidzul Qur'an Ar-Rahmani di Ciputat Tangerang Selatan. Jurnal IImiah Wahana Pendidikan, 6(2), 104-109.

Sunarmintyastuti, L., Suprapto, H. A., Sandiar, L., Leksono, A. W., \& Widiyarto, S. (2020). penyuluhan kewirausahaan dan pemberdayaan siswa yatim piatu di Ciputat Tangerang Selatan Banten. Abidumasy Jurnal Pengabdian Kepada Masyarakat, 1(2), 24-29.

Supandi, A., Sahrazad, S., Wibowo, A. N., \& Widiyarto, S. (2020). Analisis kompetensi guru: pembelajaran revolusi industri 4.0. Prosiding Samasta.

Vernia, D. M., Widiyarto, S., Narsih, D., \& Tiwinyanti, L. (2020). Sosialisasi dan pembekalan strategi pemasaran produk olahan pisang pada siswa pondok. Jurnal Pengabdian UntukMu NegeRI, 4(1), 125-128.

Vernia, D. M., Widiyarto, S., Wulansari, L., \& Rusdi, M. (2018). Penyuluhan dalam meningkatkan partisipasi program dana desa. Prosiding Sembadha, 1(1), 72-78.

Widiyarto, S., \& Sartono, L. N. (2020). Analisis nilai pendidikan karakter dan moral film koala kumal. Pena Kreatif: Jurnal Pendidikan, 9(2), 50-53.

Widiyarto, S., Narsih, D., Ati, A. P., Vernia dkk., D. M., \& Alifah, S. (2020). Pelatihan pajak pph 21 dalam rangka membangun kesadaran pajak pada siswa SMK Bangun Persada Bekasi. Intervensi Komunitas, 2(1) 